\title{
副咽頭間隙に刺入した乳児箸異物例
}

\author{
河野 敏朗・石戸谷淳一・遠藤＼cjkstart亮・佃＼cjkstart守*

\section{A Infant Case of a Chopstick as a Foreign Body in the Parapharyngeal Space}

\author{
Toshiro Kawano, Junichi Ishitoya and Ryo Endou \\ (Yokohama University Medical Center)
}

\author{
Mamoru Tsukuda \\ (Yokohama City University Graduate School of Medicine)
}

\begin{abstract}
We sometimes experience infant cases leading to unexpected deaths due to foreign bodies. It is often difficult to identify the cause or foreign body invasion by asking questions directly to a child. We experienced an infant case of a chopstick passing through the soft palate, reaching the parapharyngeal space near the inner carotid artery circumference. At the first medical examination, we could not detect the tip of the chopstick, in the pharynx. Using 3-directional-CT images, we could locate the tip of the chopstick in the parapharyngeal space near the inner carotid artery circumference. Under general anesthesia, we could remove the tip of the chopstick from the parapharyngeal space near the inner carotid artery with an endoscope trans-orally.

It is important to investigate positional conditions between a foreign body and the vessels in the parapharyngeal space. Images such as enhancing 3-directional-CT before the operation is useful.

Furthermore, we have to be careful of the late neurosis by pencil-injury in the region and pay close attention to respiratory tract management.
\end{abstract}

Key words : chopstick, foreign body, parapharyngeal space, pencil-injury

はじめに

乳幼児の異物誤飲の原因はさまざまであり，時に思い がけない死亡事故に発展することもある122).さらには患 者本人から経過などを問診し，原因や異物の同定をする ことも困難で, 診断に苦慮し，治療に難橴することもし ばしばである，今回われわれは，箸をのどに刺入した副 咽頭間隙異物の乳児 1 例を経験した. 初診時, 口腔・咽 頭表面から異物を確認することができなかった.さらに， 3 方向 CT 画像にて箸が副咽頭間隙の内頸動脈周囲まで 達しているのを確認した. 異物と副咽頭間隙の内頸動脈
との解剖学的位置関係を CT 画像で確認後, 脈管などの 周囲組織損傷に注意し，内視鏡を用いて経口腔的に摘出 することができた。術後に咽頭後壁の腫脹を認め, 上気 道閉塞も心配されたため経口挿管を翌日朝まで試みた。 術後, 内頸動脈閉塞症の神経症状は認められなかった。 小児の咽頭異物症例の注意点を中心に文献的考察を加え 報告する。

\section{症例}

症例：1歳 3 力月, 女児. 
主訴：咽頭痛。

家族歴：特記事項なし。

既往歴：特記事項なし。

現病歴：2007 年 2 月 21 日午前 8 時頃自宅にて箸をの どに刺してしまったと近医を受診した。近医での単純 CT 画像検査にて内頸動脈付近の副咽頭間隙にまで達する箸 が認められたため, 精查加療目的にて同日当科を紹介受 診し, 緊急入院となった。近医での単純 CT では䈉と内 頸動脈との位置関係が確認できず，再度当院にて造影 3 方向 CT 画像を撮影した。

現症：意識は清明であり，母親に抱かれているときに は笑顔がみられ，疼痛による号泣などは認めなかった。 口腔内肉眼所見にて軟口蓋に箸の刺入の箅所と思われる 損傷部位を確認することができた（図 1)。さらに鼻腔か ら喉頭ファイバーを挿入し, 咽頭壁を観察したが箸の異 物は確認することができなかった。 出血は口腔, 咽頭内 にはなく, さらに刺入部位は同定困難であった。脳神経 学的異常所見は認めなかった。

画像所見: Axial-CT 画像では左内頸動脈の約 $4 \mathrm{~mm}$ 内 側に折れた箸の先端が認められ, 周囲組織はやや腫脹し, 咽頭後壁の腫脹が認められた (図 $2 \mathrm{a}$ ). 3 方向 CT ではど のスライスにおいても䈐の頭蓋内への刺入や頭蓋骨骨折 などは認められなかった（図 $2 \mathrm{~b} ， \mathrm{c}$ )。

手術経過：CT 画像による評価の結果, 箸と内頸動脈 との位置関係を確認後, 摘出可能と判断した。始めに全 身麻酔下に内視鏡的に鼻腔からのアプローチを試みたが

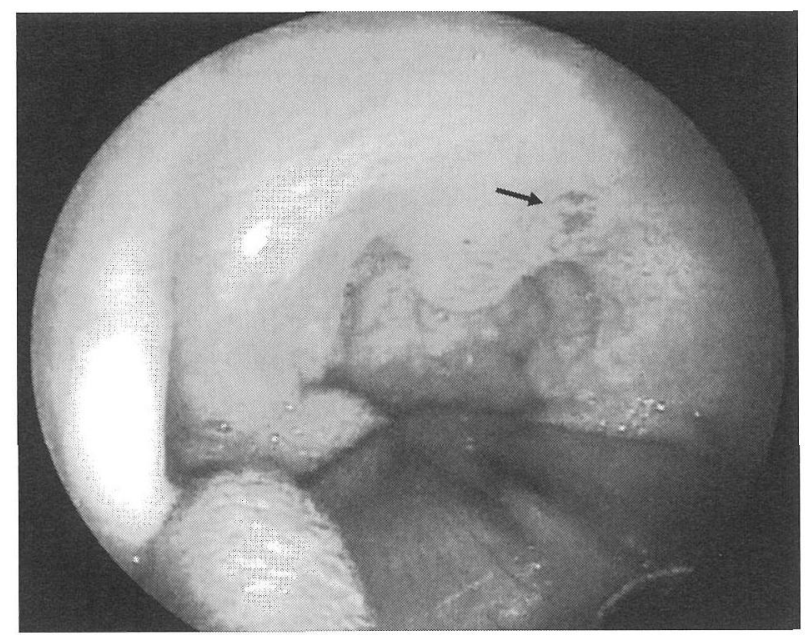

図 1 口腔内所見 左軟口蓋に刺入部位と思われる䇢所を認める (矢印)。
鈿子類の挿入が困難であった。次に口圔扁桃摘出用開口 器を装着し,さらに鼻腔よりネラトンカテーテルを挿入, 軟口蓋を挙上して口腔内功内視鏡的アプローチを試み た。これにより，より広い視野を確保することが可能と なった。箸の刺入部位と思わ机る部位のアデノイドを ESS 用の截除鉗子にて鉦除していくと箸の折れた先端を 確認することができた（図 3)。折れた箸の後端を把持し 摘出した (図 4). 摘出時に拍動性の出血は認めなかった。

術後経過 : 術後, やや咽頭後壁を中心に腫脹が認めら れ, 上気道閉塞も心配されたので, 手術終了後も抜管せ ず翌日まで挿管のまま経過観察とした。第 2 日目の朝に 喉頭ファイバーにて上気道狭窄がないことを確認後, 抜 管した。 その後, 脳神経学的症状や呼吸苦等なく, 全身 状態む良好のため第 3 日目に退院となった。

\section{考察}

日常診療において乳児，小児異物はしばしば遭遇する 疾患である. 大人の異物疾患と異なり乳児, 小児では急 変し重篤な状態に陷る可能性が高くなる. 幼少児の異物 の特徵としてはビーズ, プラスチックなどの玩具, ボタ ン，鉛筆や消しゴムなどの筆記具が多( ${ }^{3)}$. 幼少児の場 合には異物を気道汇詰め気道異物として長期間放置さ れ，気管支炎や喘息などと診断され経過観察されている 症例も少なからずある。ささらには気道に異物を詰めた死 亡事故の報告もある122).小児異物で注意しなければなら ないことは患者自身の訴えを確認することがほとんど困 難なため，喉頭ファイバー検查を含めた視診や触診にて も明らかに異物が確認できなくても，異物の体内への残 存が疑わ机る場合は積極的に CT などの画像診断を行う ベきと考える。

部位別に異物の特徴をみると上咽頭では主に外傷や裂 傷などによる異物が多い。大人の異物では銅製雷管の爆 発による上咽頭異物の報告 ${ }^{4)}$ ある。 上咽頭では食物の 通過にはほとんど関与しないため, 異物の種類む中, 下 咽頭とは違いがあるものと思われる。上咽頭異物摘出は 局所麻酔下での摘出時には気道異物にならないよう注意 が必要である5)、口腔を除いた中咽頭異物で多いのが魚 骨5) であり，特に口蓋扁桃に刺入している魚骨異物症例 の報告が多く, 中咽頭異物の中でも $50 \sim 70 \%$ を占める ${ }^{6}$. 口腔で多い異物は箸7) や歯ブラシ8) であり，小児に多い のが特徴である。さらに下咽頭では魚骨の他, 義菌, 針 金，餅，ちくわ，レンコン，こんにやくの報告9110) があ 


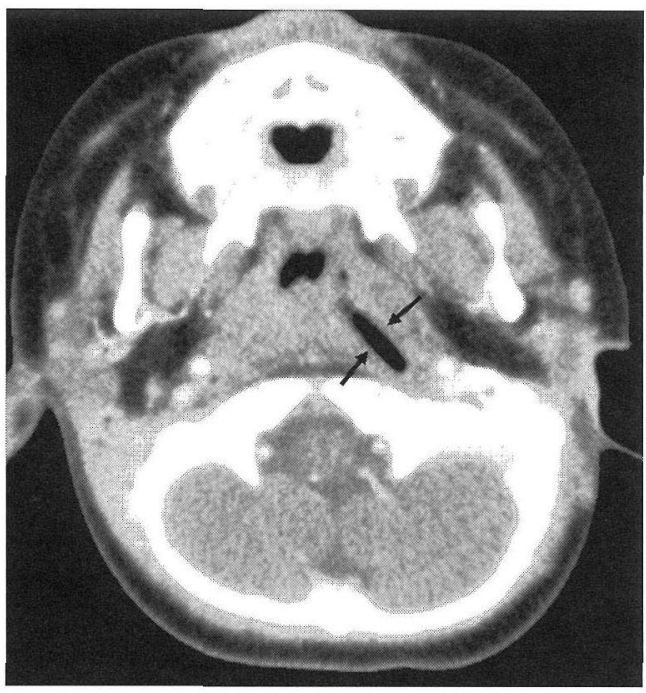

a

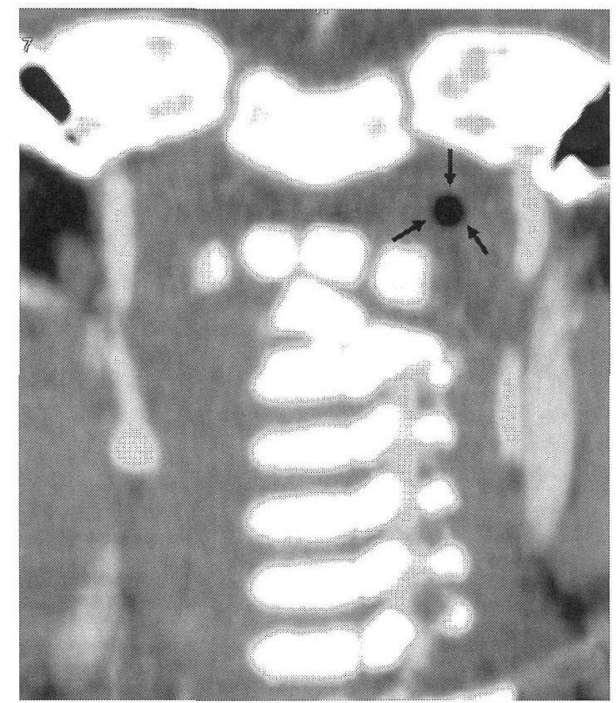

c

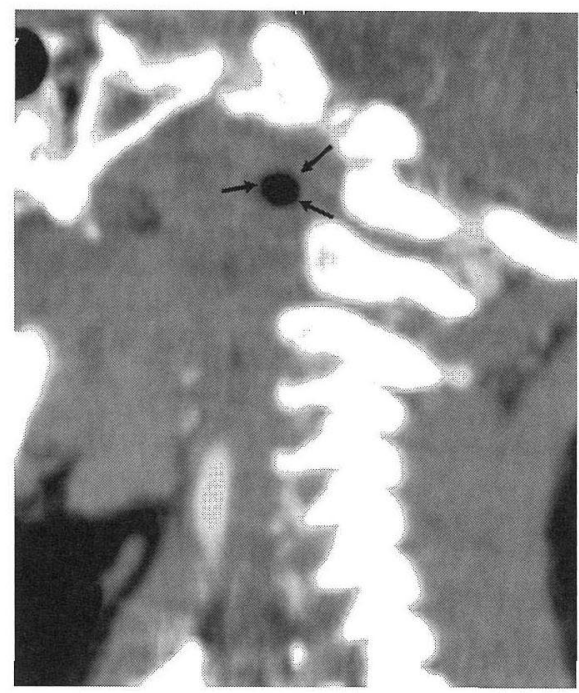

b
図 2 造影 CT 画像 ( $\mathrm{a}$ : 軸位断, $\mathrm{b}$ : 矢状断, $\mathrm{c}$ : 冠状断) 左副咽頭間隙の内頸動脈内側に䈉の先を認める（矢 印).
り，認知症や脳血管障害を伴う高齢者に多い傾向があ る5)。食道異物では小児では特に硬貨などが多く大人で は，魚骨，PTP，義歯㕶多いと報告されている ${ }^{11) . ~}$

重篤な報告としては箸や歯ブラシなどをくわえて転倒 した乳幼児が内頸動脈を閉塞し片麻痺を生じたとの報 告12) や, 乳児の口腔内刺傷に続発した中大脳動脈閉塞に よる脳梗塞症例などの報告13) がある。小児では解剖学的 に口腔から咽頭壁にかけて距離も大人に比較し短く, 咽 頭壁も脆弱なため内頸動脈閉塞症（pencil injury）を発症 する危険性が高い.内頸動脈閉塞症は内頸動脈が頸椎と 異物の力で圧迫され動脈内膜が傷害されて生じ，受傷後
48 時間以内に発症することが多く，数々の神経症状を呈 する8).今回の症例では明らかな内頸動脈損傷は CT 画像 上認められなかったが, 箸の先端が内頸動脈まで $1 \mathrm{~cm}$ 以 内であることが確認されていたことから箸による内頸動 脈の圧迫の可能性もあり，受傷後少なくとも2 日は経過 観察が必要であったと思われる。

内頸動脈閉塞症は 1936 年 Caldwell ${ }^{14)}$ の報告以来，口 腔内外傷によるものは国内外20例以上の報告がされてい る ${ }^{15) 16)}$. 口腔内外傷に続発する内頸動脈閉塞は先端が 尖ったものなどを口にくわえたまま転倒することによっ て生じることが多く，報告例の中でも小児例が大半を占 


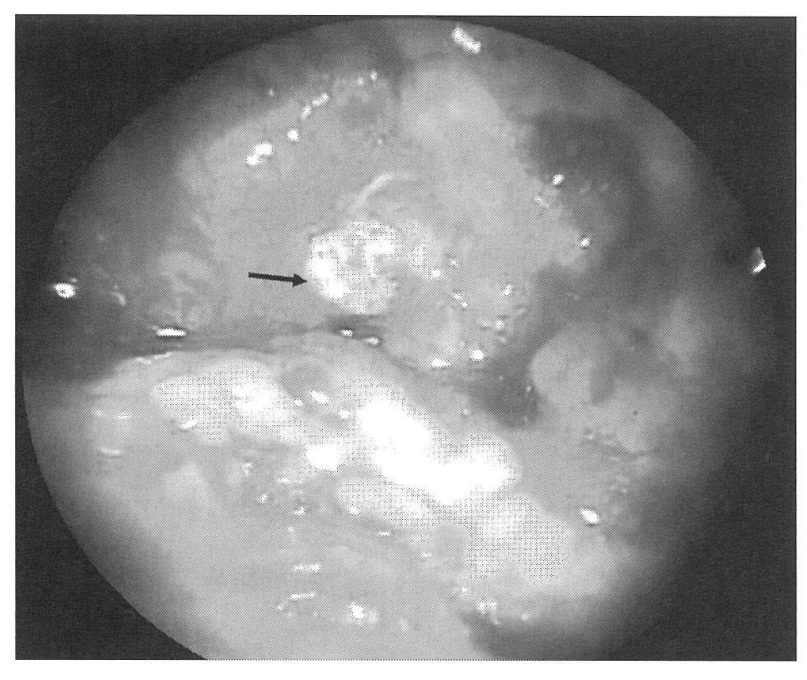

図 3 内視鏡下の上咽頭所見 上咽頭に埋没している箸の先が認められる (矢印)。
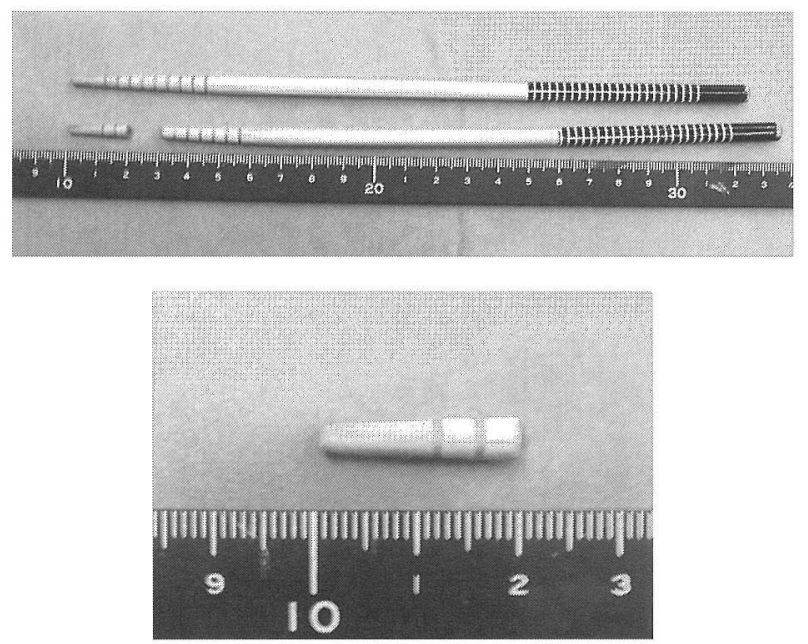

図 4 摘出された箸

める。転落などによって口にくわえた異物により咽頭を 受傷し,さらには受傷後出血を伴っていることが多い17). また本疾患での特徵に latent period が存在し, 受傷直後 からら症状が出現することはまれであり, 受傷後 1 時間以 上経てから発症するものが $90 \%$ 以上であるとも報告され ている18). 受傷後 3 時間から 3 日間の間に神経症状出現 がみられるとの報告19) もあるが, 多くの症例では受傷後 48時間以内に症状が発症することが特徴的所見と考光ら れている12).

本症例では, 結果的には受傷後 48 時間以上の入院期間
があり，幸いにも内頸動脈閉塞症を疑う症状が認められ なかった。 日常診療においては乳幼児の口腔内外傷はよ く遭遇する疾患であり, 軽微な外傷として見逃されるこ ともある. 乳幼児の口腔内外傷や異物の症例で内頸動脈 閉塞症が疑われる場合は必要に応じ入院し, 症状がなく ても少なくとも受傷後48時間以内は神経症状や呼吸状態 などの注意深い観察が必要と思われた。

\section{まとめ}

1.内頸動脈付近の副咽頭間隙に刺入した箸異物乳児 の 1 例を経験した。

2. 摘出前の造影 3 方向 CT 画像が異物と脈管の位置関 係を確認するのに有用であった。

3. 内頸動脈閉塞症や摘出術後の気道管理も注意が必 要と思われた。

\section{参考文献}

1）加納栄三: 小児の事故と予防.小览科 $29: 1311 \sim 1322,1988$.

2) 古賀慶次郎: 気道異物により死亡した小昌の 14 剖検例の検 討。日気管食道会報 $42: 323 \sim 329,1991$.

3）山田弘之：2. 鼻腔・副鼻腔異物. 耳鼻・頭頸外科 $77: 277$ $\sim 281,2005$.

4）猪本雄一郎：上咽頭異物（銅製雷管破片）の 1 症例. 耳鼻 展望 $35: 309 \sim 312,1992$.

5）石井賢治, 松原 篤: 口腔・咽頭異物. 耳鼻・頭頸外科 77 : $283 \sim 287,2005$.

6）高根宏展：魚骨異物の診断と治療. JOHNS 9：457～462, 1993.

7）小林逸朗：口腔内ハシ刺入による高位頸髄の障害. 臨神経 $21: 607 \sim 609,1981$.

8）小田直治：副咽頭間隙に刺入した歯ブラシ異物の 1 例. 松 江市立医誌 $8: 95 \sim 98,2004$.

9）伊藤裕之：下咽頭の食道異物.耳鼻・頭頸外科 $60 ： 677 \sim$ 680, 1988.

10）今村裕美子：魚骨異物を主訴とした下咽頭針金異物の 1 例. 京都市病紀 $21: 74 \sim 77,2001$.

11）山本昌彦:5. 食道異物. 耳鼻·頭頸外科 $77: 295 \sim 300,2005$.

12）篠原幸人：口腔内外傷に続発した内頸動脈閉塞症の 1 例. 神経内科 $4: 437 \sim 446,1976$.

13）井川千鶴子：口腔内刺傷に続発した中大脳動脈閉塞症の 1 幼児例. 小児臨 $38: 181 \sim 187,1985$.

14) Caldwell JA : Posttraumatic thrombosis of internal carotid artery. Report of two cases. Am J Surg $32: 522,1936$.

15）門田紘輝：口腔内外傷に起因した小児内頸動脈閉塞症の 1 例. 小児の脳神 $5: 169 \sim 176,1980$.

16）高山 順：口腔内外傷に続発した内頸動脈閉塞の 1 幼児例. 
小児臨 $36: 565 \sim 570,1983$.

17) Martin $\mathrm{N}$ and Warren GC : Thrombosis of the internal carotid artery due to intra-oral trauma. South Med J $62: 103 \sim 107$, 1969.

18) Little JM, May J, Vanderfield GK, et al. : Traumatic thrombosis of the internal carotid artery. Lancet $2: 926 \sim 930,1969$.

19) Hengerer AS, DeGroot TR, Rivers RJ, et al. : Internal carotid artery thrombosis following soft palate injuries: a case report and review of 16 cases. Laryngoscope 94:1571 1575, 1984 .

原稿受付: 平成19年 3 月 27 日

原稿採択：平成19年 5 月 1 日

別刷請求先：河野敏朗

厂232-0024 横浜市南区浦舟町4-57

横浜市立大学附属市民総合医療センター耳鼻咽喉科 